\title{
Treatment of lead and arsenic poisoning in anuric patients - a case report and narrative review of the literature
}

\author{
Chun-Yuan Hsiao', Chip Gresham ${ }^{2,3}$ and Mark R. Marshall ${ }^{1,4,5^{*}}$ (B)
}

\begin{abstract}
Background: Heavy metal poisoning can cause debilitating illness if left untreated, and its management in anuric patients poses challenges. Literature with which to guide clinical practice in this area is rather scattered.

Case presentation: We present a case of symptomatic lead and arsenic poisoning from use of Ayurvedic medicine in a 28-year-old man with end-stage kidney disease on chronic hemodialysis. We describe his treatment course with chelating agents and extracorporeal blood purification, and review the relevant literature to provide general guidance.

Conclusion: Cumulative clinical experience assists in identifying preferred chelators and modalities of extracorporeal blood purification when managing such patients. However, a larger body of real-world or clinical trial evidence is necessary to inform evidence-based guidelines for the management of heavy metal poisoning in anuric patients.
\end{abstract}

Keywords: Arsenic poisoning, Lead poisoning, Chelators, Anuria, Extracorporeal blood purification

\section{Background}

Heavy metal poisoning involving arsenic (Ars) and lead $(\mathrm{Pb})$ can cause debilitation and death [1-3]. The major route of elimination of heavy metals is usually through the kidneys [1,2], and in cases of poisoning this elimination can be enhanced by chelating agents [4-7]. The most common agents are dimercaprol, also known as British Anti-Lewisite (BAL); calcium-disodium-ethylene diaminetetraacetic acid ( $\left.\mathrm{CaNa}_{2} \mathrm{EDTA}\right)$; dimercaptosuccinic acid, also known as succinmer (DMSA); and 2,3Dimercapto-1-propanesulfonate (DMPS). So long as renal function is not severely impaired, treatment of poisoning does not normally require adjunctive extracorporeal blood purification (EBP), which is inferior to removal of heavy metals by normally functioning kidneys [8-11].

\footnotetext{
* Correspondence: mrmarshall@middlemore.co.nz;

markrogermarshall@icloud.com; mark_roger_marshall@baxter.com

'Department of Renal Medicine, Middlemore Hospital, Counties Manukau

Health, Private Bag 93311, Otahuhu, Auckland 1640, New Zealand

${ }^{4}$ Faculty of Medical and Health Sciences, University of Auckland, Auckland

1142, New Zealand

Full list of author information is available at the end of the article
}

In patients who are anuric, whether from acute kidney injury (AKI) or end-stage kidney failure (ESKF), EBP is the only means for removal of heavy metals, and a critical intervention alongside general measures to support and preserve organ function. When using EBP, chelating agents are generally mandatory to achieve rapid removal and meaningful detoxification. Although these general principles are well known, there is only a small published literature reporting a wide range of practices often without clear links to outcomes. For a clinician facing such a case in clinical practice, choosing the right chelating agent for a given patient can be daunting. We describe an instructive case and review the relevant literature, thereby providing general guidance on the timing, type, dose and duration of both chelation therapy during EBP for heavy metal poisoning in anuric patients.

\section{Case presentation}

A 28-year-old man on maintenance hemodialysis (HD) was diagnosed with steroid-resistant primary focal segmental glomerulosclerosis causing nephrotic syndrome in February 2006. There was only a partial response to ciclosporin, and he reached end-stage kidney failure 
requiring hemodialysis in August 2011. He presented with progressive global motor weakness, tremor and hallucinations in December 2011. This was preceded by eight months of polyarthralgia, constipation, abdominal pain, and nausea and vomiting, and one month of severe neuropathic pain in all limbs, nightmares and involuntary vocalization. To enquiry, he admitted taking Ayurvedic medicine over a long but unquantifiable duration.

Physical examination revealed a blood pressure of 140/ $90 \mathrm{mmHg}$, a heart rate of 76 beats per minute and a respiratory rate of 18 per minute. His cardiovascular, respiratory, abdominal and joint examinations were unremarkable. Alopecia was notable, although we could not identify any skin or nail abnormalities. The striking neurological findings were moderate-to-severe muscle weakness involving the face, neck and all limbs; absent reflexes at C6, C7 and S1; impaired proprioception in the hands and feet; and a patchy disturbance of light touch and pinprick over all limbs.

He had normocytic normochromic anemia, with erythrocyte basophilic stippling noted on two of his numerous peripheral smears. His erythrocyte porphyrins level was $5 \mathrm{umol} / \mathrm{L}$ (normal $<1.8 \mathrm{umol} / \mathrm{L}$ ). Nerve conduction studies revealed axonal sensorimotor polyradiculoneuropathy. Other investigations included magnetic resonance imaging of brain, cerebral spinal fluid analysis, autoimmune, infection and metabolic screens, and were all unremarkable.

At this point, a provisional diagnosis of heavy metal poisoning was considered, based upon his history of Ayurvedic medicine exposure. His blood $\mathrm{Pb}$ level was found to be significantly elevated at $6.3 \mathrm{umol} / \mathrm{L}$ (normal $<0.47 \mathrm{umol} / \mathrm{L}$ ), but his blood mercury level was normal at $5 \mathrm{nmol} / \mathrm{L}$ (normal $<50 \mathrm{nmol} / \mathrm{L}$ ). His blood was not tested for Ars, although pooled (scalp, chest and arms) hair samples were sent for testing at this time. Parathyroid hormone level was $7.5 \mathrm{pmol} / \mathrm{L}$ (normal 1.7 - 7.3 $\mathrm{pmol} / \mathrm{L}$ ). The ayurvedic products recovered from the patient's domicile contained high levels of Ars (50 to $290 \mathrm{mg} / \mathrm{kg}$ ), $\mathrm{Pb}$ (28 to $12,000 \mathrm{mg} / \mathrm{kg}$ ) and mercury (5 to $75,000 \mathrm{mg} / \mathrm{kg}$ ).

Due to initial unavailability of $\mathrm{CaNa}_{2}$ EDTA and DMPS, we treated him for 5 days with continuous venovenous haemodiafiltration (CVVHDF) and BAL administered intramuscularly at $4 \mathrm{mg} / \mathrm{kg}$ every $4 \mathrm{~h}$. When $\mathrm{CaNa}_{2} \mathrm{EDTA}$ became available, we switched him to thrice weekly standard high-flux HD with the $1 \mathrm{~g}$ of $\mathrm{CaNa}_{2}$ EDTA administered over $1 \mathrm{~h}$, given $1-3 \mathrm{~h}$ before HD. His nightmares, involuntary vocalisation and gastrointestinal symptoms resolved over a few weeks, although his peripheral neuropathy and alopecia persisted with only mild improvement. After a month, the results of initial testing for Ars became available. The level in his hair samples was $1.21 \mathrm{mg} / \mathrm{kg}$ (normal $<0.1 \mathrm{mg} / \mathrm{kg}$ ), suggesting ongoing exposure in the 2 to 3 months prior to hospital admission. Our assessment was that the residual peripheral neuropathy was most likely attributable to Ars, as it tends to cause a sensorimotor polyneuropathy often presenting with predominantly sensory symptoms, while $\mathrm{Pb}$ poisoning usually presents with minimal to no sensory involvement $[3,12]$. On the basis of this assessment, we felt that it was reasonable to attempt a course of chelation specifically for Ars. We chose DMPS on the basis of its favourable toxicity profile, which was administered to him orally $2-3 \mathrm{~h}$ before each HD. We discontinued this medication after 2 weeks, however, due to a lack of clinical improvement and evidence of mobilisation of Ars, with levels that remained consistently undetectable in both blood and dialysate $(<0.05 \mathrm{umol} / \mathrm{L})$.

In total, we provided 8 weeks of $\mathrm{Pb}$ chelation, after which time the blood $\mathrm{Pb}$ level decreased and remained less than $1.2 \mathrm{umol} / \mathrm{L}$ (see Fig. 1). Over the following 8 months of follow up, there was only mild improvement of his tremors and weakness, and the peripheral neuropathy persisted, presumably on the basis of chronic arsenicosis. There were no chelator-associated adverse effects during the course of the treatment.

\section{Discussion and conclusions}

\section{Toxicokinetics of Lead and arsenic}

$\mathrm{Pb}$ and Ars are heavy metals with low atomic weights $[2,13]$, but despite this are not rapidly removed by EBP without chelation due to other toxicokinetic properties. With $\mathrm{Pb}, \sim 99 \%$ binds to erythrocytes within the first hour, following which there is rapid distribution in the body with binding to sulfhydryl and carboxyl groups on a wide variety of structural and functional proteins in the central and peripheral nervous, cardiovascular, renal, reproductive, musculoskeletal, hematopoietic, and other organ systems. Over time, $\sim 95 \%$ of total body $\mathrm{Pb}$ burden is stored in bone [2]. These properties reduce the availability $\mathrm{Pb}$ for extracorporeal removal without a chelator.

Ars has a low serum protein binding ranging from $5.3 \%$ (inorganic trivalent arsenic) to $6.5 \%$ (inorganic pentavalent arsenic) [13], but a high volume of distribution $(3.3$ to $4 \mathrm{~L} / \mathrm{kg})$ and rapid redistribution from serum to tissues (phase 1 half-life $1-2 \mathrm{~h}$, with $90 \%$ of Ars redistributing within $3 \mathrm{~h}$ ) [14]. Theoretically, then, there is a therapeutic window for early EBP without chelation in first few hours after ingestion. For instance, in a case of massive Ars poisoning with anuric AKI, one group used high-flux HD for $4 \mathrm{~h}$ without a chelator, achieving an extracorporeal Ars clearance of $85 \mathrm{ml} / \mathrm{min}$ and removal of $8 \mathrm{mg}$ of Ars [10]. In another report, a similar regimen was shown to remove approximately $67 \%$ of serum Ars, albeit in chronic HD patients who were not poisoned with normal background serum 


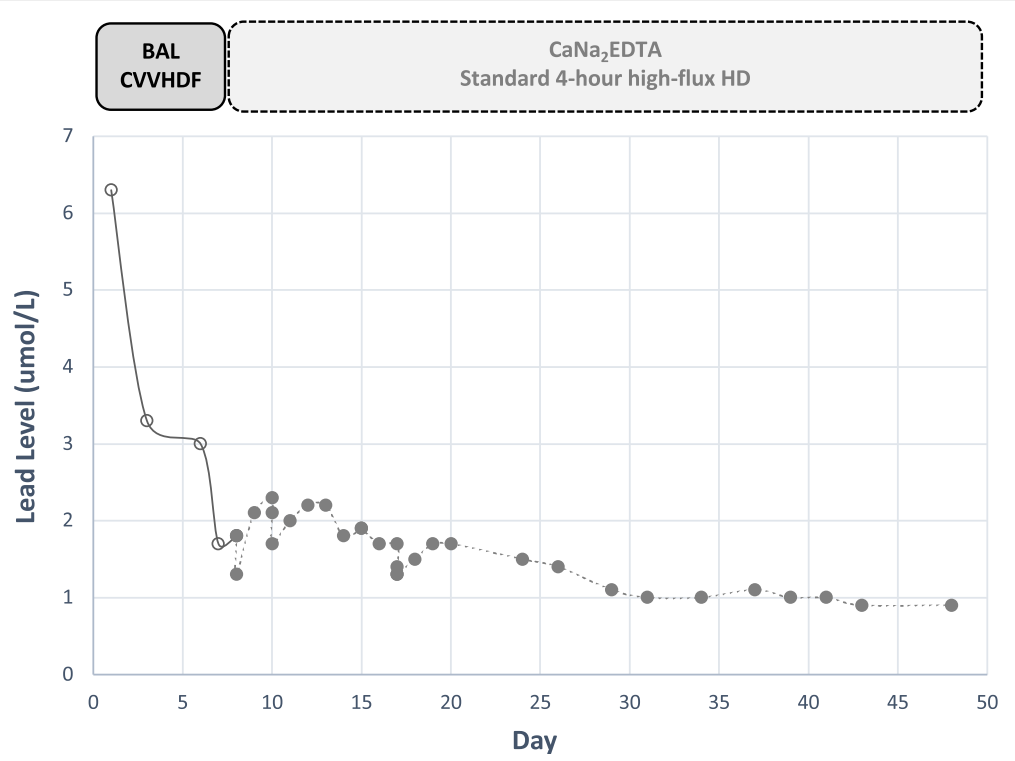

Fig. 1 Blood lead concentration-time graph in relation to the use of different chelating agents and different modalities of extracorporeal tblood purification. Solid line - BAL (4 mg/kg IM every $4 \mathrm{~h}$ ) with continuous venovenous hemodiafiltration (CWHDF); dashed line - CaNa 2 EDTA (1 g IV) given 1 to $3 \mathrm{~h}$ before 4 -h high-flux hemodialysis (HD)

arsenic levels averaging $6.47 \mu \mathrm{g} / \mathrm{l}[15]$. Despite these reports, a chelator is strongly recommended for all stages of acute Ars poisoning in anuric patients, since it will always enhance availability of the metal in serum for dialysis [10], and minimise chances of subsequent morbidity and mortality.

\section{Chelation therapy}

It is important to select an appropriate chelator that is suitable for treatment of the specific poisoning, and dosed correctly to minimise chelator-induced adverse effects. In the setting of anuria, there is also accumulation of the chelator-metal complex, and without removal (by either by native kidneys or EBP) this will lead to redistribution of the metal into central nervous system. As such, EBP should be promptly administered with chelation for optimal removal of both chelated and non-chelated metals. In addition, it should be remembered that poisoned patients with AKI invariably develop metabolic acidosis, and this may decrease the effectiveness of chelators. Tables 1, 2 and 3 summarise the pharmacologic basis of the chelating agents, and the literature describing their use in treating $\mathrm{Pb}$ and Ars poisoning. Adverse effects are generally dose related and a non-exhaustive list is included in Table 1.

\section{Dimercaprol (BAL)}

BAL is a chelator originally used in Ars poisoning, Nowadays, it is most commonly used in conjunction with $\mathrm{CaNa}_{2}$ EDTA for severe $\mathrm{Pb}$ poisoning or $\mathrm{Pb}$-induced encephalopathy, where it is administered $4 \mathrm{~h}$ prior to giving
$\mathrm{CaNa}_{2} \mathrm{EDTA}$ (see section on $\mathrm{CaNa}_{2} \mathrm{EDTA}$ below). BAL itself has a low molecular weight of $124 \mathrm{Da}$, and BAL-Pb and BAL-Ars chelated complexes have molecular weights of $455 \mathrm{Da}$ and $323 \mathrm{Da}$, respectively, assuming a stable (though not well described) BAL-metal 2:1 ratio [3]. Data on protein binding in plasma are not available for BAL and its metabolites, or for protein binding and volume of distribution of BAL-Pb and BAL-Ars compounds.

BAL is administered intramuscularly in peanut oil [3]. Of note, the drug itself has a poor toxicity profile compared to other chelators. With doses of $4 \mathrm{mg} / \mathrm{kg}$ and 5 $\mathrm{mg} / \mathrm{kg}$, the incidence of reported adverse effects is as high as 14 to $65 \%$, respectively [22]. This risk is increased in anuria due to accumulation. BAL does undergo a degree of hepatic glucuronidation forming glucuronic acid conjugates [22]. Theoretically, these metabolites are more hydrophilic than BAL, and thus more easily removed by kidneys and presumably EBP [23] Notwithstanding, there is still a greater risk of adverse effects from BAL in the setting of anuria.

Literature describing ideal prescription of EBP with concurrent BAL use is limited, but longer EBP treatments theoretically allow for greater removal of the metal-chelator complex. As BAL reaches its peak concentration in serum approximately 30 to $60 \mathrm{~min}$ after intramuscular injection [3]. EBP should be performed within one hour after the administration of BAL.

There is little reported experience with BAL as a sole $\mathrm{Pb}$ chelator with EBP in setting of anuria. In the case presented in this research, we only used BAL because of 
Table 1 Chemical properties and pharmacologic basis of the chelating agents used in lead and arsenic poisoning

\begin{tabular}{|c|c|c|c|c|}
\hline & BAL & DMPS & $\mathrm{CaNa}_{2} \mathrm{EDTA}$ & DMSA \\
\hline $\begin{array}{l}\text { Amendable to } \\
\text { EBP }\end{array}$ & + & ++ & +++ & $+/-$ \\
\hline $\begin{array}{l}\text { Molecular } \\
\text { Weight (Dalton) }\end{array}$ & 124 & 228 & 374 & 182 \\
\hline $\begin{array}{l}\text { Chelate-Pb } \\
\text { Complex MW } \\
\text { (Dalton) }^{a}\end{array}$ & $\begin{array}{l}331 \\
\text { (455 if ratio is } 2: 1) \text { [3] }\end{array}$ & 434 & 540 & 389 \\
\hline $\begin{array}{l}\text { Chelate-Ars } \\
\text { Complex MW } \\
\text { (Dalton) }^{a}\end{array}$ & $\begin{array}{l}199 \\
\text { (323 if ratio is } 2: 1) \text { [3] }\end{array}$ & $\begin{array}{l}303 \\
\text { (803 if ratio is } 3: 2) \\
\text { [4] }\end{array}$ & Cannot chelate arsenic [16] & 257 \\
\hline $\begin{array}{l}\text { Administration } \\
\text { Route }\end{array}$ & IM in peanut oil medium & $\mathrm{PO}, \mathrm{IV}$ & IV, IP, IM & $\mathrm{PO}$ \\
\hline Distribution & Lipophilic & Hydrophilic & Hydrophilic & Hydrophilic \\
\hline $\begin{array}{l}\text { Volume of } \\
\text { Distribution }\end{array}$ & High & $0.16 \mathrm{~L} / \mathrm{kg}[4]$ & $0.21 \mathrm{~L} / \mathrm{kg}[17]$ & $0.4 \mathrm{~L} / \mathrm{kg}^{\mathrm{b}}[18]$ \\
\hline Protein Binding & $\mathrm{n} / \mathrm{a}$ & $62.5 \%[19]$ & $11-19 \%[20]$ & $95 \%[21]$ \\
\hline Excretion & Renal (Major) & $\begin{array}{l}\text { Renal (46 - 59\%) } \\
\text { Biliary (extent } \\
\text { undetermined) }\end{array}$ & Renal (Major) & Renal (Major) \\
\hline LD50 (mmol/kg) & $1.48^{\mathrm{c}}[16]$ & $6.53^{c}[16]$ & $16.4[5]$ & $13.73^{c}[16]$ \\
\hline Contraindications & $\begin{array}{l}\text { Peanut allergies, hepatic dysfunction, } \\
\text { methylmercury poisoning }\end{array}$ & $\begin{array}{l}\text { None in acute } \\
\text { lead or arsenic } \\
\text { toxicity }\end{array}$ & None in acute lead toxicity & None in acute lead or arsenic toxicity \\
\hline Adverse Effects & $\begin{array}{l}\text { Nausea, vomiting, headache, } \\
\text { hypertension, pain and/or sterile } \\
\text { abscess at injection site, haemolysis in } \\
\text { G6PD-deficiency, chelation of essential } \\
\text { metals in prolonged use }\end{array}$ & $\begin{array}{l}\text { Allergic reaction, } \\
\text { nausea, vomiting, } \\
\text { Steven-Johnson } \\
\text { syndrome (rare) }\end{array}$ & $\begin{array}{l}\text { Fatigue, headache, mild } \\
\text { AST/ALT elevations, } \\
\text { nephrotoxicity, chelation of } \\
\text { essential metals in } \\
\text { prolonged use }\end{array}$ & $\begin{array}{l}\text { Nausea, vomiting, diarrhoea, mild } \\
\text { AST/ALT elevations, Fever, rash, } \\
\text { reversible neutropenia (rare), } \\
\text { chelation of essential metals in } \\
\text { prolonged use }\end{array}$ \\
\hline
\end{tabular}

$M W$ molecular weight, $I M$ intramuscular, $I V$ intravenous, $P O$ oral, $I P$ intraperitoneal, $P b$ lead, Ars arsenic

a: the ratio of chelate-metal complex is presumably $1: 1$ as data is limited; $n / a$ : not available

b: based on primates

c: based on mice IP

the initial unavailability of $\mathrm{CaNa}_{2}$ EDTA and DMPS. Notwithstanding, we showed that CVVHDF was effective in removing BAL-Pb (Fig. 1), allowing us to use the full recommended dose of BAL, whilst minimising the risk of blood $\mathrm{Pb}$ rebound that is usually seen after intermittent HD, as well as the risk of significant accumulation of the chelator in the body. Despite our positive experience, we believe BAL should not be used as a sole chelator in anuric patients if other options are available.

There are several reports of using BAL with EBP for acute Ars poisoning in the setting of impaired kidney function. In two anuric patients treated with BAL, Ars removal was between 50 and $100 \%$ greater with even low flux-HD compared to that removed by their residual kidney function, consistently removing between 2 and 6 mg of Ars per treatment [8, 24]. With more modest degrees of renal impairment, Ars removal with HD is still considerable, but less important than native kidney removal. For instance, one report described $10.7 \mathrm{mg}$ of Ars eliminated by the kidneys over $24 \mathrm{~h}$ in a patient with a serum creatinine of $27 \mathrm{mg} / \mathrm{L}$, compared to only $8.2 \mathrm{mg}$ eliminated by a $4 \mathrm{~h}$ high flux $\mathrm{HD}$ session [10].
Importantly, the efficacy of Ars removal with EBP is often expressed as clearance, and which is sometimes not increased by BAL $[8,10,24,25]$. This should not be misinterpreted as showing limited efficacy - in all cases, BAL increased the serum concentration of Ars available to EBP per unit time, leading to greater removal (i.e. when expressed in mass balance terms) despite similar clearance.

The reported use of BAL with EBP for acute Ars poisoning is summarized in Table 3 [14, 25-28]. The potential benefits of BAL in this setting needs to be carefully weighed against the risks, which arise from its relatively greater lipophilicity compared to DMSA and DMPS. This can lead to abrupt mobilization of Ars from tissue, and redistribution into central nervous system with acute exacerbation of neuro-encephalopathy [31]. To our knowledge, this complication has not yet been reported in the literature in the clinical setting, this is primarily because of careful measures that are universally taken to avoid its occurrence. In our patient, any such effect was obviated by EBP in the form of CVVHDF immediately after administration of BAL 
Table 2 Extracorporeal removal of lead by different modes of extracorporeal blood purification in patients with acute or chronic lead intoxication after an initial administration of intravenous $500 \mathrm{mg}$ to $1000 \mathrm{mg}$ of $\mathrm{CaNa}_{2} \mathrm{EDTA}$

\begin{tabular}{|c|c|c|c|c|c|c|c|}
\hline Patients & $\begin{array}{l}\text { Renal } \\
\text { Function }\end{array}$ & $\begin{array}{l}\text { Mode of } \\
\text { Dialytic Therapy }\end{array}$ & $\begin{array}{l}\text { Initial Blood } \\
\text { Pb Level }\end{array}$ & $\begin{array}{l}\text { Post-dialysis } \\
\text { Blood Pb Level }\end{array}$ & $\begin{array}{l}\text { Dialytic Pb } \\
\text { Removal }\end{array}$ & $\begin{array}{l}\text { Urinary Pb } \\
\text { Excretion }\end{array}$ & Outcome \\
\hline $\begin{array}{l}1-\text { Smith } \\
{[37]}\end{array}$ & Normal & $H D-2 h$ & $3.1 \mathrm{mg} / \mathrm{g}$ & $1.0 \mathrm{mg} / \mathrm{g}$ & $3.4 \mathrm{mg}$ & $\mathrm{n} / \mathrm{a}$ & Died \\
\hline 2 & Normal & $H D-2 h$ & $2.7 \mathrm{mg} / \mathrm{g}$ & $1.3 \mathrm{mg} / \mathrm{g}$ & $3.0 \mathrm{mg}$ & $\mathrm{n} / \mathrm{a}$ & Improved encephalopathy \\
\hline 3 & Normal & $\mathrm{HD}-30 \mathrm{~min}$ & $1.6 \mathrm{mg} / \mathrm{g}$ & $1.1 \mathrm{mg} / \mathrm{g}$ & $1.0 \mathrm{mg}$ & $\mathrm{n} / \mathrm{a}$ & Remained severely encephalopathic \\
\hline 4 & Normal & $H D-2 h$ & $1.8 \mathrm{mg} / \mathrm{g}$ & $0.7 \mathrm{mg} / \mathrm{g}$ & $2.2 \mathrm{mg}$ & $\mathrm{n} / \mathrm{a}$ & Died \\
\hline $\begin{array}{l}1- \\
\text { Mehbod } \\
{[38]}\end{array}$ & GFR $<10$ & CAPD & $\mathrm{n} / \mathrm{a}$ & $\mathrm{n} / \mathrm{a}$ & $16.9 \mathrm{mg} / 20 \mathrm{~h}$ & $0.12 \mathrm{mg} / 20 \mathrm{~h}$ & $\begin{array}{l}\text { Weakness; constipation and anaemia } \\
\text { improved }\end{array}$ \\
\hline 2 & Normal & CAPD & $\mathrm{n} / \mathrm{a}$ & $\mathrm{n} / \mathrm{a}$ & $1.90 \mathrm{mg} / 20 \mathrm{~h}$ & $0.50 \mathrm{mg} / 20 \mathrm{~h}$ & $\begin{array}{l}\text { No immediate improvement; no } \\
\text { long-term follow up }\end{array}$ \\
\hline 3 & Normal & CAPD & $\mathrm{n} / \mathrm{a}$ & $\mathrm{n} / \mathrm{a}$ & $1.48 \mathrm{mg} / 20 \mathrm{~h}$ & $0.70 \mathrm{mg} / 20 \mathrm{~h}$ & $\begin{array}{l}\text { No immediate improvement; no } \\
\text { long-term follow up }\end{array}$ \\
\hline 4 & Normal & CAPD & $1.25 \mathrm{mg} / \mathrm{L}$ & $0.75 \mathrm{mg} / \mathrm{L}$ & $2.00 \mathrm{mg} / 20 \mathrm{~h}$ & $0.40 \mathrm{mg} / 20 \mathrm{~h}$ & $\begin{array}{l}\text { Improved encephalopathy; no } \\
\text { long-term follow up }\end{array}$ \\
\hline $\begin{array}{l}1- \\
\text { Pedersen } \\
{[39]}\end{array}$ & Normal & $H D-9 h$ & 1.36 mg/L & $0.68 \mathrm{mg} / \mathrm{L}$ & $\mathrm{n} / \mathrm{a}$ & $\mathrm{n} / \mathrm{a}$ & $\begin{array}{l}\text { Serum } \mathrm{Pb} \text { level } 0.28 \mathrm{mg} / \mathrm{L} \text { after } \\
7 \text { weeks; no clinical outcome reported }\end{array}$ \\
\hline $\begin{array}{l}1-\text { Roger } \\
{[40]}\end{array}$ & ESKF & CAPD & $1.40 \mu \mathrm{mol} / \mathrm{L}$ & $\mathrm{n} / \mathrm{a}$ & $\begin{array}{l}9.29 \mu \mathrm{mol} \\
\text { over } 4 \text { days }\end{array}$ & $\begin{array}{l}2.96 \mu \mathrm{mol} / \text { day } \\
\text { on day } 4\end{array}$ & $\begin{array}{l}\text { Improved mental state but peripheral } \\
\text { neuropathy progressed after } 4 \text { months }\end{array}$ \\
\hline $\begin{array}{l}1-\text { Kessler } \\
{[41]}\end{array}$ & ESKF & $\mathrm{HF}$ & $0.279 \mathrm{mg} / \mathrm{L}$ & $\mathrm{n} / \mathrm{a}$ & $1.650 \mathrm{mg} /$ day $^{\mathrm{a}}$ & & $\mathrm{n} / \mathrm{a}$ \\
\hline 2 & ESKF & $\mathrm{HF}$ & $0.131 \mathrm{mg} / \mathrm{L}$ & $\mathrm{n} / \mathrm{a}$ & $1.450 \mathrm{mg} /$ day $^{\mathrm{a}}$ & & $\mathrm{n} / \mathrm{a}$ \\
\hline 3 & ESKF & $\mathrm{HF}$ & $0.361 \mathrm{mg} / \mathrm{L}$ & $\mathrm{n} / \mathrm{a}$ & $1.152 \mathrm{mg} /$ day $^{\mathrm{a}}$ & & Died \\
\hline 4 & ESKF & $\mathrm{HF}$ & $0.281 \mathrm{mg} / \mathrm{L}$ & $\mathrm{n} / \mathrm{a}$ & $1.267 \mathrm{mg} /$ day $^{\mathrm{a}}$ & & $\mathrm{n} / \mathrm{a}$ \\
\hline 5 & ESKF & CAPD & $0.265 \mathrm{mg} / \mathrm{L}$ & $\mathrm{n} / \mathrm{a}$ & 0.334 mg/day & 0.476 mg/day & $\mathrm{n} / \mathrm{a}$ \\
\hline $\begin{array}{l}1-\text { Kessler } \\
{[42]}\end{array}$ & ESKF & $\mathrm{HF}$ & $0.280 \mathrm{mg} / \mathrm{L}$ & $\mathrm{n} / \mathrm{a}$ & $3.300 \mathrm{mg} /$ day $^{\mathrm{a}}$ & & $\mathrm{n} / \mathrm{a}$ \\
\hline 2 & ESKF & CAPD & $0.265 \mathrm{mg} / \mathrm{L}$ & $\mathrm{n} / \mathrm{a}$ & $0.710 \mathrm{mg} /$ day $^{\mathrm{a}}$ & & $\mathrm{n} / \mathrm{a}$ \\
\hline $\begin{array}{l}1-\text { Barats } \\
{[43]}\end{array}$ & ESKF & $\mathrm{HD}$ & $0.690 \mathrm{mg} / \mathrm{L}$ & $0.110 \mathrm{mg} / \mathrm{L}^{\mathrm{b}}$ & $\mathrm{n} / \mathrm{a}$ & $\mathrm{n} / \mathrm{a}$ & $\begin{array}{l}\text { Resolved encephalopathy and motor } \\
\text { neuropathy }\end{array}$ \\
\hline $\begin{array}{l}1- \\
\text { Roberts } \\
\text { [44] }\end{array}$ & ESKF & $\mathrm{HD}$ & $0.49 \mu \mathrm{g} / \mathrm{L}$ & $\mathrm{n} / \mathrm{a}$ & $0.24 \mathrm{mg}$ & $0.025 \mathrm{mg}$ & Lead mobilisation test \\
\hline
\end{tabular}

ESKF end-stage kidney failure, GFR glomerular filtration rate, $H D$ haemodialysis, $H F$ haemofiltration, CAPD continuous ambulatory peritoneal dialysis, $P b$ lead ${ }^{a}$ : combined urinary removal of lead over $24 \mathrm{~h}$ and dialysis; ${ }^{b}: 3$ months after chelation; $\mathrm{n} / \mathrm{a}$ : not available

continuously for numerous days, providing prompt and uninterrupted removal of mobilized Ars thereby avoiding accumulation and post-dialysis rebound. Given that the diagnosis of Ars poisoning was delayed in our case, it was reassuring that we detected no clinical deterioration in our patient with BAL and CVVHDF, even though we did not look for evidence of mobilisation of Ars at the time.

The benefit of chelators in chronic arsenicosis is debated, but generally not recommended as most health effects in this condition are irreversible. In support of this, a small randomised-placebo controlled trial involving 22 patients showed BAL to be ineffective for this condition [32], and there was no significant improvement in our patient's peripheral neuropathy after chelation for several weeks.

\section{Dimercaptosuccinic acid (DMSA/Succimer)}

DMSA is an orally-administered water-soluble analogue of BAL that has a higher therapeutic index. It is one of the chelating agents of choice for acute and chronic $\mathrm{Pb}$ poisoning in patients with normal kidney function. DMSA can also be considered for the treatment acute Ars poisoning.

DMSA has a low molecular weight of $182 \mathrm{Da}$, and a low volume of distribution of approximately $0.4 \mathrm{~L} / \mathrm{kg}$ [18]. The molecular weights of DMSA-Pb and DMSAArs complex are $389 \mathrm{Da}$ and $257 \mathrm{Da}$, respectively, based 


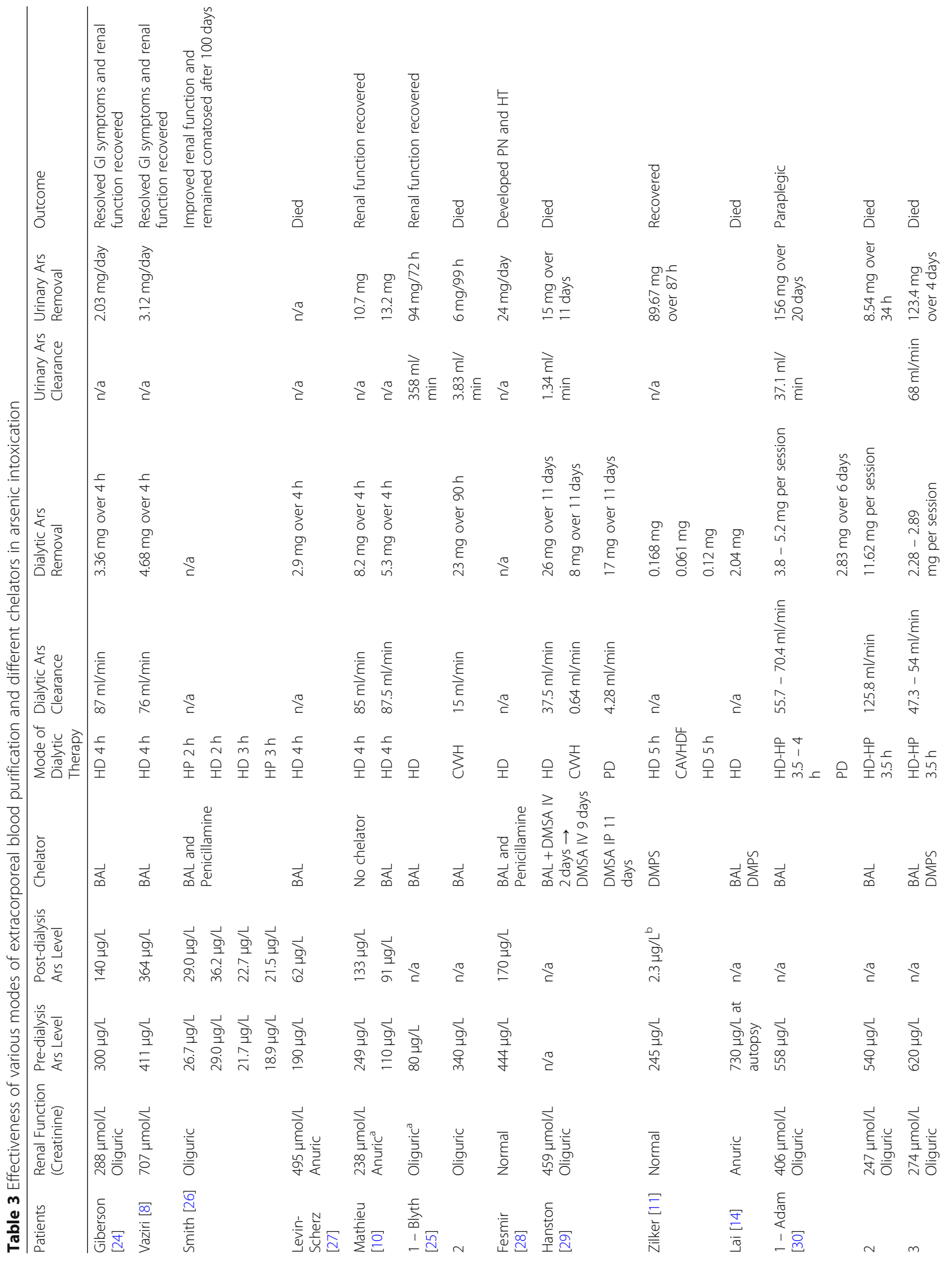




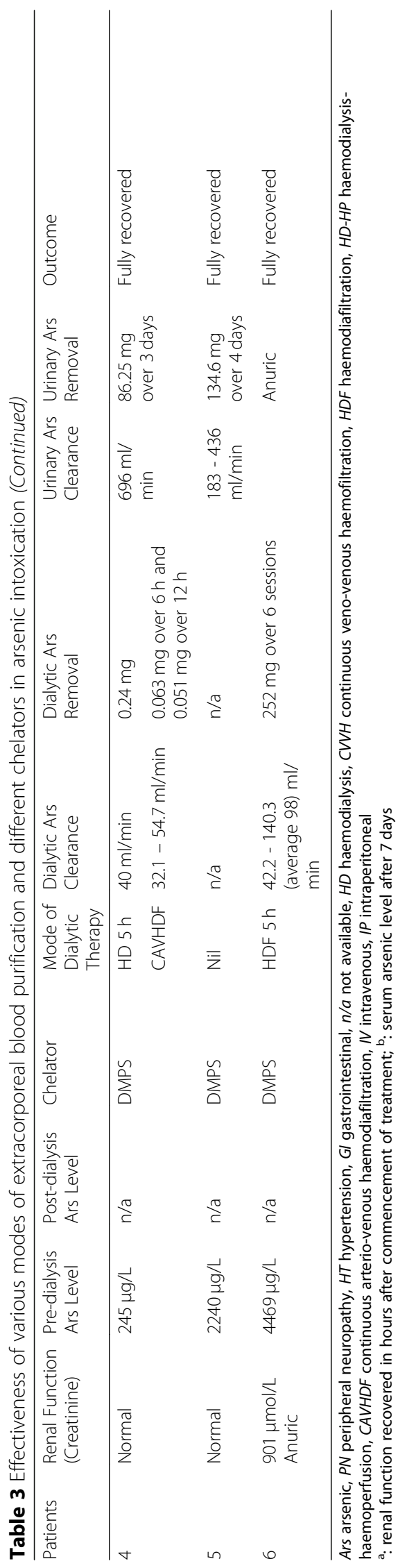


Table 4 General guidance on chelation therapy and extracorporeal blood purification (EBP) in oliguric or anuric patients with lead and/or arsenic poisoning ${ }^{\text {a }}$

\begin{tabular}{|c|c|c|c|}
\hline \multirow{2}{*}{$\begin{array}{l}\text { Heavy metal poisoning } \\
\text { Acute severe } \mathrm{Pb} \text { poisoning with } \\
\text { encephalopathy }\end{array}$} & \multicolumn{2}{|l|}{ Chelation } & \multirow{2}{*}{$\begin{array}{l}\text { EBP Modality } \\
\text { HDF or high-flux HD } \\
\text { CRRT if unstable or BAL is used }\end{array}$} \\
\hline & 1st line: & $\begin{array}{l}\text { BAL } 4 \mathrm{mg} / \mathrm{kg} \text { IM every } 4-6 \mathrm{~h}[3,22] \\
\text { AND } \\
\mathrm{CaNa} \mathrm{a}_{2} \text { EDTA } 25-50 \mathrm{mg} / \mathrm{kg}(\max 3 \mathrm{~g}) \text { IV over } \\
24 \mathrm{~h} \text { on CRRT, } \\
\text { begin } 4 \mathrm{~h} \text { after BAL }[41,42,44]\end{array}$ & \\
\hline & $2^{\text {nd }}$ line: & $\begin{array}{l}\mathrm{CaNa}_{2} \text { EDTA } 1 \mathrm{~g} \mathrm{IV} \text { over } 1 \mathrm{~h} \text {, give } 1-3 \mathrm{~h} \text { before } \\
\mathrm{HD} \text { or } 25-50 \mathrm{mg} / \mathrm{kg}(\max 3 \mathrm{~g}) \text { IV over } 24 \mathrm{~h} \text { on CRRT } \\
{[41,42,44]} \\
\text { OR } \\
\text { BAL } 4 \mathrm{mg} / \mathrm{kg} \text { IM every } 4-6 \mathrm{~h} \text { on CRRT }[3,22]\end{array}$ & \\
\hline & 3rd line: & $\begin{array}{l}\text { DMPS } 3-5 \mathrm{mg} / \mathrm{kg}(\max 250 \mathrm{mg}) \text { IV every } \\
4 \mathrm{~h}[49-51]^{\mathrm{b}}\end{array}$ & \\
\hline & \multicolumn{2}{|l|}{ DMSA ${ }^{c}$} & \\
\hline \multirow[t]{4}{*}{$\begin{array}{l}\text { Acute } \mathrm{Pb} \text { poisoning without } \\
\text { encephalopathy but still requiring } \\
\text { chelation }\end{array}$} & 1st line: & $\begin{array}{l}\text { CaNa } \mathrm{CDTTA}_{1} 1 \mathrm{~g} \text { IV over } 1 \mathrm{~h} \text {, give } 1-3 \mathrm{~h} \text { before HD } \\
\text { or } 25-50 \mathrm{mg} / \mathrm{kg}(\max 3 \mathrm{~g}) \text { IV over } 24 \mathrm{~h} \text { on CRRT } \\
{[41,42,44]}\end{array}$ & \multirow[t]{4}{*}{$\begin{array}{l}\text { HDF or high-flux HD } \\
\text { CRRT if unstable or BAL is used }\end{array}$} \\
\hline & 2nd line: & DMPS $100-300$ mg PO every $8 \mathrm{~h}[49,52,53]^{\mathrm{b}}$ & \\
\hline & 3rd line: & BAL 4 mg/kg IM every $4-6$ hours $[3,22]$ & \\
\hline & $D M S A^{c}$ & & \\
\hline \multirow[t]{4}{*}{$\begin{array}{l}\text { Chronic } \mathrm{Pb} \text { poisoning without } \\
\text { encephalopathy requiring chelation }\end{array}$} & 1st line: & $\begin{array}{l}\text { CaNa }{ }_{2} \text { EDTA } 1 \mathrm{~g} \text { IV over } 1 \mathrm{~h} \text {, give } 1-3 \mathrm{~h} \text { before HD } \\
\text { or } 25-50 \mathrm{mg} / \mathrm{kg}(\max 3 \mathrm{~g}) \text { IV over } 24 \mathrm{~h} \text { on CRRT } \\
{[41,42,44]}\end{array}$ & \multirow{4}{*}{$\begin{array}{l}\text { HDF or high-flux HD } \\
\text { CRRT if unstable or BAL is used } \\
\text { PD could be considered if } \\
\mathrm{CaNa}_{2} \text { EDTA is used }\end{array}$} \\
\hline & 2nd line: & DMPS 100-300 mg PO every $8 \mathrm{~h}[49,52,53]^{\mathrm{b}}$ & \\
\hline & 3rd line: & BAL 4 mg/kg IM every 4-6 h $[3,22]$ & \\
\hline & $D M S A^{c}$ & & \\
\hline \multirow[t]{3}{*}{ Ars poisoning (acutely ill) } & 1st line: & DMPS 3-5 mg/kg (max 250 mg) IV every $4 \mathrm{~h}$ [49-51] & \multirow{3}{*}{$\begin{array}{l}\text { HDF or high-flux HD } \\
\text { CRRT if unstable or BAL is used }\end{array}$} \\
\hline & 2nd line: & BAL 4 mg/kg IM every 4-6 h $[3,22]$ & \\
\hline & $D M S A^{c}$ & & \\
\hline Ars poisoning (chronic / subacute) ${ }^{d}$ & \multicolumn{2}{|c|}{ DMPS 100-300 mg PO every $8 \mathrm{~h}[52,53]$} & HDF or high-flux HD \\
\hline
\end{tabular}

CRRT continuous renal replacement therapy, HDF hemodiafiltration, $H D$ hemodialysis, $P D$ peritoneal dialysis, MWCO molecular weight cut-off

a The above chelation dosing recommendations are a result of our literature review and personal experience and should be considered as a guideline only. We strongly recommend discussion with a poison center or medical toxicologist in conjunction with these recommendations for each individual case, therapeutic endpoints of chelation and side-effects. 2nd and 3rd line treatments may be considered if 1 st line treatments are unavailable

${ }^{\mathrm{b}}$ DMPS dose for $\mathrm{Pb}$ chelation is extrapolated from the Ars chelation dose

' The efficacy DMSA with severe renal impairment is unclear, but it may be considered in conjunction with a high MWCO dialysis membrane if the other chelators are unavailable. For both Pb and Ars: $10 \mathrm{mg} / \mathrm{kg}$ PO every $8 \mathrm{~h}$ for 5 days, then $10 \mathrm{mg} / \mathrm{kg}$ every $12 \mathrm{~h}$ [33]

${ }^{d}$ The role of chelation, if any, in chronic/subacute Ars poisoning is unclear

on the 1:1 DMSA-metal complex ratio. However, DMSA is $95 \%$ protein-bound in plasma [21], although there are no data on protein binding of DMSA-metal complexes. This makes DMSA (and probably its DMSA-metal complex) unfavourable for extracorporeal removal. Adding more limitations to the use DMSA in anuric patients is that DMSA appears to be a prodrug in humans. It conjugates with cysteine to form DMSA-cysteine disulfides as an active chelator by an unclear mechanism in kidney's proximal tubular cells [33]. This important process is unlikely to occur in completely impaired kidneys. Interestingly, DMSA-cysteine disulfides is not formed in mice, rats and rabbits, and the unaltered DMSA is able to chelate $\mathrm{Pb}$ to some degree in these species [33].

There is limited literature describing the use of DMSA with EBP. Though hemoperfusion is useful in removing highly protein-bound molecules [34], the affinity of DMSA and its chelated complex to the activated charcoal or resin cartridge is unknown, and to our knowledge there is no reported experience in human subjects with $\mathrm{Pb}$ and Ars poisoning. There are other practical disadvantages to hemoperfusion, including the need for frequent change of cartridges due to rapid saturation, the limited shelf-life of the cartridges, the lack of clinical experience with this form of due to infrequent use, and the generally high cost $[34,35]$. Hantson et al reported generally low extracorporeal Ars removal using intravenous DMSA and other EBP techniques in a 26-year-old oliguric patient who probably had $10 \mathrm{~g}$ of arsenic trioxide ingestion over 2 weeks [29]. The extracorporeal Ars clearance was $0.64 \mathrm{ml} / \mathrm{min}$ for continuous veno-venous haemofiltration $(\mathrm{CVVH}), 4.28 \mathrm{ml} / \mathrm{min}$ for peritoneal 
dialysis (PD) and $37.51 \mathrm{ml} / \mathrm{min}$ for HD. Sheabar et al showed in vitro that DMSA actually inhibited Ars removal across a standard dialysis membrane, but not across a dialysis membrane with molecular weight cutoff (MWCO) of 12,000 - 14,000 [36]. Presumably, the large protein-chelator-metal complexes are unable to cross a standard dialysis membrane, but able to cross a more porous one.

Because of our patient's encephalopathy, and the limited evidence and experience with DMSA, we chose BAL (both drugs were available to us at the time) and continued with BAL until his encephalopathy resolved and $\mathrm{CaNa}_{2}$ EDTA became available. DMSA with or without EBP in anuric patients with $\mathrm{Pb}$ or Ars poisoning should probably only be considered if no other options are available, and then only with a high MWCO dialysis membrane.

\section{Calcium-disodium Edetate ( $\left.\mathrm{CaNa}_{2} \mathrm{EDTA}\right)$}

$\mathrm{CaNa}_{2}$ EDTA is one of the chelating agents of choice in $\mathrm{Pb}$ poisoning for its effective $\mathrm{Pb}$ chelation, high therapeutic index, and good cumulative clinical experience of favourable outcomes as summarized in Table 2. It is usually given intravenously but can be administered intramuscularly and intraperitoneally. The chelator has potential to cause AKI as a direct adverse event, and this risk increases at doses of more than $75 \mathrm{mg} / \mathrm{kg} /$ day [5]. Other disadvantages of this agent are its poor oral bioavailability at less than $5 \%$, and its associated risk of depletion of essential metals such as iron, zinc and manganese [3].

Combining $\mathrm{CaNa}_{2}$ EDTA with BAL is recommended in $\mathrm{Pb}$ poisoning induced encephalopathy, while $\mathrm{CaNa}_{2} \mathrm{EDTA}$ can be used as a monotherapy in those patients requiring chelation but without signs of $\mathrm{Pb}$ induced encephalopathy $[6,45]$. Compared with DMSA, $\mathrm{CaNa}_{2}$ EDTA is better at mobilising $\mathrm{Pb}$ from the bone and forms a water-soluble compound that is ideal for urinary elimination and removal by EBP. Of note, combined chelation with DMSA and $\mathrm{CaNa}_{2} \mathrm{EDTA}$ has been shown to be more effective than either $\mathrm{CaNa}_{2}$ EDTA or DMSA is given individually $[46,47]$. However, DMSA is not appropriate for anuric patients as discussed previously.

$\mathrm{CaNa}_{2}$ EDTA has a molecular weight of $374 \mathrm{Da}$ and the molecular weight of $\mathrm{Pb}-\mathrm{Na}_{2} \mathrm{EDTA}$ complex is $542 \mathrm{Da}$. $\mathrm{CaNa}_{2}$ EDTA is hydrophilic and has a small volume of distribution of $0.21 \mathrm{~L} / \mathrm{kg}$ [17]. The protein binding of EDTA in plasma is not well described, but ranges from 11 to $19 \%$ [20]. These properties make $\mathrm{CaNa}_{2}$ EDTA and its complexes theoretically ideal for extracorporeal removal. Despite this, however, a study demonstrated that a 4-h HD session with a high-flux dialysis membrane (even if the dialysis treatment continued to infinity) could only eliminate 60 to $65 \%$ of administered $1 \mathrm{~g} \mathrm{CaNa}{ }_{2} \mathrm{EDTA}$ and the rest of the administered compound could not be accounted for [44].

In reported cases of $\mathrm{Pb}$ poisoning in the setting of AKI and ESKF, clinical outcomes with $\mathrm{CaNa}_{2} \mathrm{EDTA}$ and various EBPs are largely favourable; only one patient death has been reported, and clinical manifestations induced by $\mathrm{Pb}$ poisoning in the remaining 9 patients had either resolved or improved [38, 40-43]. Negative outcomes have only been reported in a single older case series. In this report, 4 paediatric patients presented with encephalopathy and extremely elevated serum $\mathrm{Pb}$ levels, ranging from 7.72 to $14.97 \mathrm{umol} / \mathrm{L}$ ( 1.6 to $3.1 \mathrm{mg} / \mathrm{g}$ ) as compared with 0.63 to $3.3 \mathrm{umol} / \mathrm{L}$ in the other reported cases. $\mathrm{Al}$ though these patients had normal renal function, the severity of their presentation led to their treatment with 50 to $75 \mathrm{mg} / \mathrm{kg}$ of EDTA and adjunctive HD. In each of these patients, only 1 to $3.4 \mathrm{mg}$ of chelated $\mathrm{Pb}$ were removed per HD session [37], probably due to the ineffectiveness of HD which was performed using a Kolff-Brigham rotating drum artificial kidney wound with 26 loops of cellophane. Unsurprisingly, two patients died and the other 2 remained significantly encephalopathic despite treatment.

PD is generally not an ideal EBP for acute poisonings, due to its slow clearance of toxins. In chronic Pb poisoning, however, the literature shows that peritoneal dialysis can be safely used in combination with $\mathrm{CaNa}_{2}$ EDTA so long as there is no clinical urgency [38, 40-42]. This is particularly well described in one case series: the amount of chelated $\mathrm{Pb}$ extracted by PD (1.48 to $2 \mathrm{mg}$ ) exceeded that by normal functioning kidneys $(0.4$ to $0.7 \mathrm{mg}$ ) over $20 \mathrm{~h}$ in 3 patients with chronic $\mathrm{Pb}$ poisoning; the corresponding amounts were $16.8 \mathrm{mg}$ by PD and $0.12 \mathrm{mg}$ by chronically diseased kidneys (eGFR $<10 \mathrm{ml} / \mathrm{min}$ ) in another [38]. Critically, this approach is not recommended for acute $\mathrm{Pb}$ poisoning, and is only appropriate for chronic cases.

We suggest $\mathrm{CaNa}_{2}$ EDTA in combination with BAL as the first line treatment for anuric patients with severe $\mathrm{Pb}$ poisoning or $\mathrm{Pb}$-induced encephalopathy. If encephalopathy is not present, but chelation is needed for $\mathrm{Pb}$ poisoning, $\mathrm{CaNa}_{2} \mathrm{EDTA}$ may be used alone $[6,45]$. There is categorically no role for $\mathrm{CaNa}_{2} \mathrm{EDTA}$ in Ars poisoning. It is difficult to determine the ideal timing of initiating EBP after administrating the chelator, although the most reports begin immediately after a one-hour intravenous infusion of $\mathrm{CaNa}_{2} \mathrm{EDTA}$ is completed. Longer EBP treatments will likely allow for greater removal of chelator-metal complexes.

Given the available evidence, our patient was managed with using BAL and CVVHDF as the initial treatment. This was done so to avoid worsening of encephalopathy and development of BAL related adverse effects, and for maximal removal BAL- $\mathrm{Pb}$ complex. He was switched to 
$\mathrm{CaNa}_{2}$ EDTA and high-flux HD as soon as $\mathrm{CaNa}_{2}$ EDTA became available, and his encephalopathy resolved. The patient responded to the combination favourably without experiencing any major adverse events and his $\mathrm{Pb}$ levels receded promptly. It is important to note that $\mathrm{CaNa}_{2}$ EDTA is generally administered as a $25-50 \mathrm{mg} /$ $\mathrm{kg}$ intravenous infusion over twenty four hours; however we administered $1 \mathrm{~g}$ over one hour prior to HD based on the literature describing those with ESKF [41, 42, 44].

\section{2,3-Dimercapto-1-propanesulfonate (DMPS)}

DMPS is a water-soluble analogue of BAL that has been used for heavy metals poisoning (mainly mercury, Ars and sometimes $\mathrm{Pb}$ ) for many years. It appears to be less effective than DMSA or $\mathrm{CaNa}_{2}$ EDTA in treating Pb poisoning [6], although good clinical outcomes have occasionally been reported [48]. There are numerous case reports showing successful treatment of Ars poisoning, as summarized in Table 3 [4, 9, 49-51].

DMPS has favourable properties for extracorporeal removal, including modest protein binding of about $62.5 \%$, hydrophilia and a low volume of distribution $(0.16 \mathrm{~L} / \mathrm{kg})$
$[4,19]$. The molecular weight of its metal complex is low based on 1:1 ratio, but it could be $834 \mathrm{Da}$ for DMPS-Ars compound if the compound ratio is $3: 2$ as has been suggested [4]. If this were the case, using highflux HD or hemodiafiltration (HDF) would theoretically be preferable.

Adam described in his thesis a series of patients with acute Ars poisoning, including a 22 year-old patient who developed anuric AKI within $18 \mathrm{~h}$ of ingesting inorganic Ars. His initial serum Ars level was $4469 \mu \mathrm{g} / \mathrm{l}$. He was treated with intravenous DMPS together with HDF. The maximum achieved extracorporeal clearance of Ars was $140 \mathrm{ml} / \mathrm{min}$, and the average clearance $98 \mathrm{ml} / \mathrm{min}$. A total of $252 \mathrm{mg}$ of Ars was extracted by daily 5-h sessions of HDF over 5 days, and his serum arsenic was reduced to $106 \mu \mathrm{g} / \mathrm{l}$. The patient recovered without long-term complications. Of note, this impressive clearance is still much lower than that achieved by the normally functioning kidneys, as illustrated by the measured clearance in another arsenic poisoned patient in the same report - after DMPS, clearance averaged $696 \mathrm{ml} /$ min. The lowest clearance in this case series was

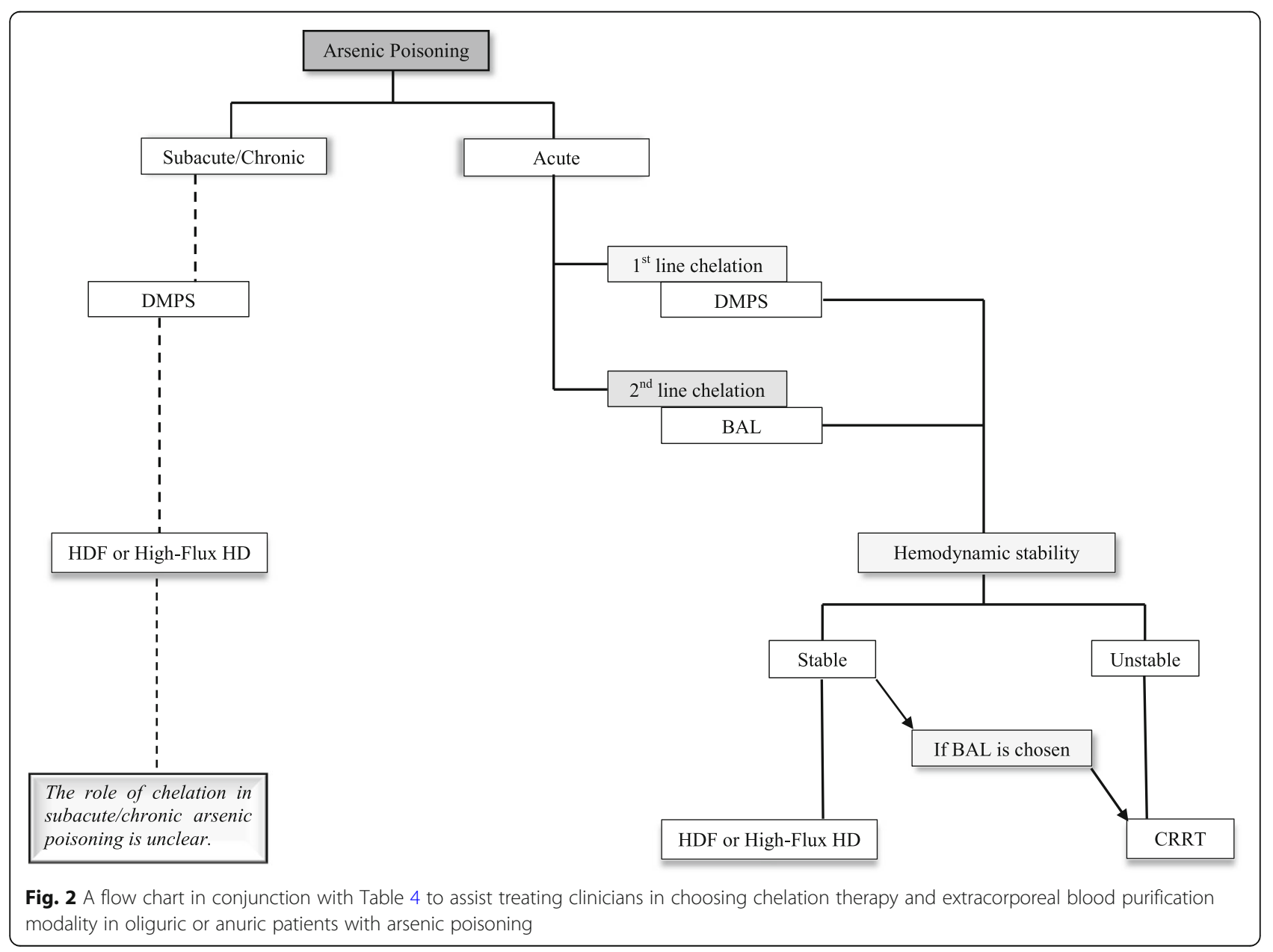


achieved in two cases treated with BAL and combined low-flux HD plus hemoperfusion (two cases $70.4 \mathrm{ml} / \mathrm{min}$ and $125.8 \mathrm{ml} / \mathrm{min}$ ) [30].

Despite the lack of definitive data, DMPS combined high-flux HD or HDF should be considered in acute Ars poisoning in auric patients. This recommendation is based on the observations of Adam above and also other reported cases $[8,10,24]$. If DMPS is given orally, EBP should be commenced within $2 \mathrm{~h}$ of the administrating the chelator, as the urinary excretion of Ars by normal functioning kidneys appears to be the greatest in the first $2 \mathrm{~h}$ [52]. Though evidence is not strong, we feel that EBP can be initiated immediately if DMPS is given intravenously, and the duration of each EBP treatment session after administrating the chelator should ideally be more than the standard $4 \mathrm{~h}$ to allow for greater removal of the chelator-metal complexes. In those with normally functioning kidneys, EBP probably provides little benefit.

Theoretically, DMPS could have been used as the sole and initial chelator for our patient with combined Ars and $\mathrm{Pb}$ poisoning. However, the severity of his $\mathrm{Pb}$ poisoning was such that DMPS was probably insufficient as first line chelation, even if it had been available to us at the time. It could potentially have been given in conjunction with BAL for maximizing both Ars and $\mathrm{Pb}$ chelation without exacerbating encephalopathy. Similarly, combining DMPS with $\mathrm{CaNa}_{2}$ EDTA would be a preferred option in the absence of encephalopathy for their favourable chemical and pharmacological properties.

As stated previously, chelators are generally not recommended in chronic arsenicosis. Having said that, DMPS has been shown to increase urinary Ars excretion even in patients with chronic arsenicosis [52]. A small randomised placebo-controlled trial and a case report demonstrated improvement in clinical symptoms caused by chronic arsenicosis using DMPS [51, 53], although the trial was not well designed. In these reports, however, all patients had normal kidney function. In contrast, a trial of oral DMPS in our patient resulted in negligible extracorporeal removal of Ars and no significant change to his peripheral neuropathy during the course of the therapy.

\section{Conclusions}

Treating heavy metal poisoning in anuric patients remains a significant challenge. Based on cumulative clinical experience to date, $\mathrm{CaNa}_{2}$ EDTA and DMPS are

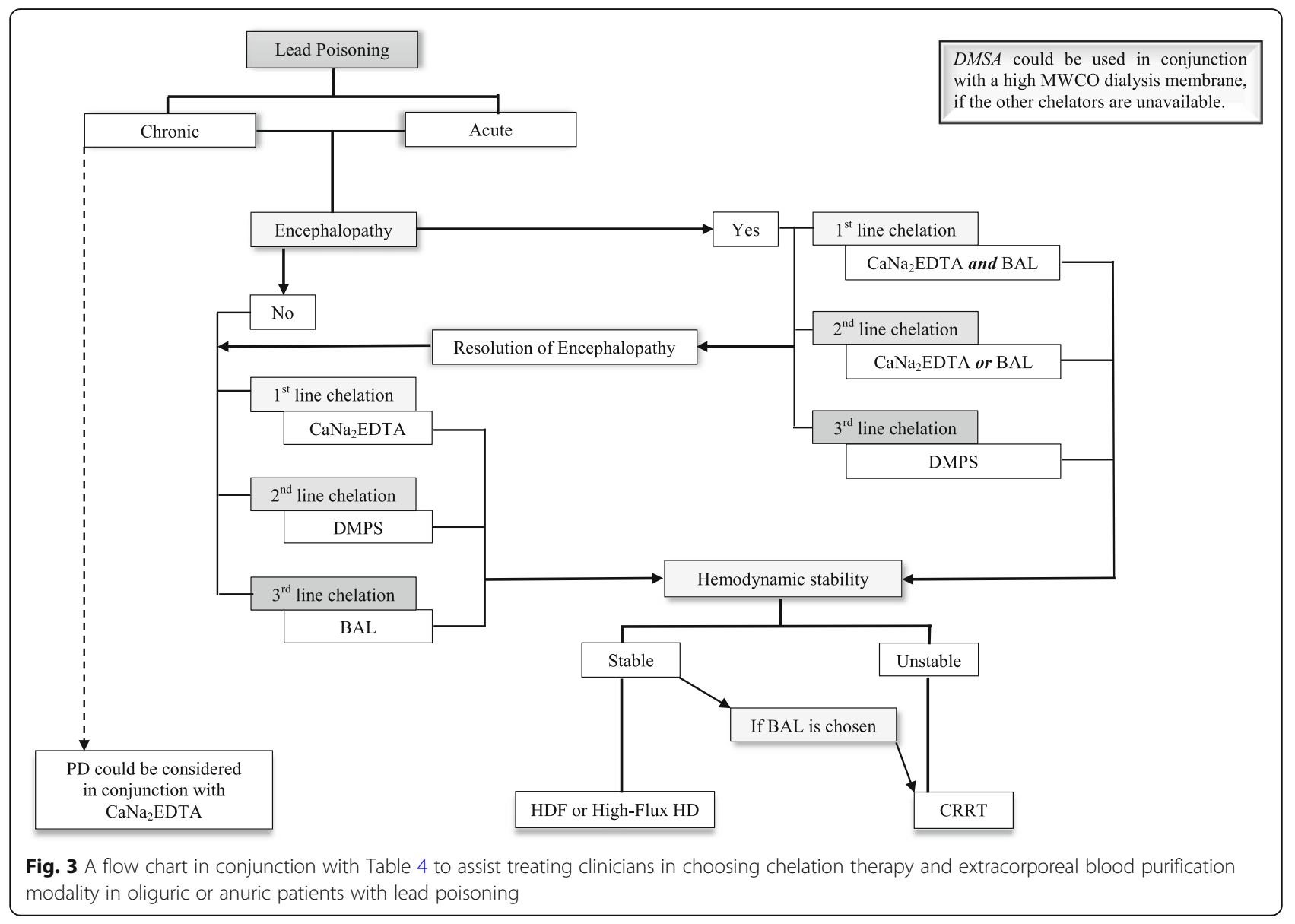


probably the safest and the most effective chelating agents for $\mathrm{Pb}$ and Ars, respectively, and DMSA should not be used in anuric patients if the other chelators are available. BAL should be used in conjunction with $\mathrm{CaNa}_{2} \mathrm{EDTA}$ for severe $\mathrm{Pb}$ poisoning or $\mathrm{Pb}$-induced encephalopathy, and may be used as the sole chelator for both $\mathrm{Pb}$ and Ars poisoning if no other chelators are available. These suggestions are summarised in Table 4 supported by Figs. 2 and 3. High-flux HD and HDF are preferred EBP modalities, but continuous renal replacement therapy should be considered in patients with haemodynamic instability or when using BAL any time to reduce the risk of developing rebound phenomena and BAL associated adverse effects. More research in this area is needed to assist in developing evidencebased treatment guidelines for acute $\mathrm{Pb}$ and Ars poisoning in this population. Finally, in all cases of poisonings, treatment decisions should generally be made in conjunction with a toxicologist and/or a local poison center, if available.

\begin{abstract}
Abbreviations
AKI: Acute kidney injury; BAL: Dimercaprol, also known as british anti-lewisite; CaNa2EDTA: Calcium-disodium-ethylenediaminetetraacetic acid; CWH: Continuous veno-venous haemofiltration; CWHDF: Continuous veno-venous haemodiafiltration; DMPS: Dimercaptopropanesulfonic acid; DMSA: Dimercaptosuccinic acid; EBP: Extracorporeal blood purification; ESKF: End-stage kidney failure; HD: Hemodialysis; HDF: Hemodiafiltration; MWCO: Molecular weight cut-off
\end{abstract}

\section{Acknowledgements}

Not applicable.

\section{Authors' contributions}

C-YH performed the data collection, review of literature, and initial drafting of the manuscript. CG and MRM provided advice to the management of this case, reviewed the literature and revised the manuscript. All authors have read and approved the manuscript.

\section{Funding}

There was no specific funding for this study.

\section{Availability of data and materials}

The original de-identified data and material is available upon request from the corresponding author at chunyuan.hsiao@middlemore.co.nz.

\section{Ethics approval and consent to participate}

The research committee of Middlemore Hospital (FWA00021560) approved this research, and the need for ethics approval was waived by the Northern A HDEC (IRB00008714) of the Ministry of Health (IORG0000895) (https://ohrp. cit.nih.gov/search/search.aspx).

\section{Consent for publication}

Written informed consent was obtained from the patient for publication of this Case Report and any accompanying images. A copy of the written consent is available for review by the Editor of this journal.

\section{Competing interests}

MRM is employed by Baxter Healthcare as the Director Medical Affairs, AsiaPacific (Renal). MRM is also a member of the Editorial Board Member of BMC Nephrology. The other authors have no actual or potential conflicts to declare.

\section{Author details}

'Department of Renal Medicine, Middlemore Hospital, Counties Manukau Health, Private Bag 93311, Otahuhu, Auckland 1640, New Zealand. ${ }^{2}$ Department of Emergency Medicine, Middlemore Hospital, Auckland 1640, New Zealand. ${ }^{3}$ National Poisons Centre, Dunedin 9054, New Zealand. ${ }^{4}$ Faculty of Medical and Health Sciences, University of Auckland, Auckland 1142, New Zealand. ${ }^{5}$ Baxter Healthcare (Asia Pacific) Pte Ltd, Singapore 189673, Singapore.

Received: 18 July 2018 Accepted: 20 September 2019

Published online: 17 October 2019

\section{References}

1. Marafante E, Vahter M, Norin H, Envall J, Sandstrom M, Christakopoulos A, Ryhage R. Biotransformation of dimethylarsinic acid in mouse, hamster and man. J Appl Toxicol. 1987;7(2):111-7.

2. Abadin H, Ashizawa A, Stevens YW, Llados F, Diamond G, Sage G, Citra M, Quinones A, Bosch SJ, Swarts SG. Toxicological Profile for Lead. Atlanta: Agency for Toxic Substances and Disease Registry; 2007: 24049859.

3. Klaassen CD. Heavy metals and heavy-metal antagonists. In: Brunton LL, Lazo JS, Parker KL, editors. Goodman \& Gilman's The Pharmacological Basis of Therapeutics 11th Ed. United States: McGraw-Hill; 2006. https://doi.org/10. 1036/0071422803.

4. Aposhian HV. DMSA and DMPS--water soluble antidotes for heavy metal poisoning. Annu Rev Pharmacol Toxicol. 1983;23:193-215.

5. Flora SJ, Pachauri V. Chelation in metal intoxication. Int J Environ Res Public Health. 2010;7(7):2745-88.

6. Chisolm JJ Jr. BAL, EDTA, DMSA and DMPS in the treatment of lead poisoning in children. J Toxicol Clin Toxicol. 1992;30(4):493-504.

7. Porru S, Alessio L. The use of chelating agents in occupational lead poisoning. Occup Med (Lond). 1996;46(1):41-8.

8. Vaziri ND, Upham T, Barton CH. Hemodialysis clearance of arsenic. Clin Toxicol. 1980;17(3):451-6.

9. Kruszewska S, Wiese M, Kolacinski Z, Mielczarska J. The use of haemodialysis and 2,3 propanesulphonate (DMPS) to manage acute oral poisoning by lethal dose of arsenic trioxide. Int J Occup Med Environ Health. 1996;9(2):111-5.

10. Mathieu D, Mathieu-Nolf M, Germain-Alonso M, Neviere R, Furon D, Wattel F. Massive arsenic poisoning--effect of hemodialysis and dimercaprol on arsenic kinetics. Intensive Care Med. 1992;18(1):47-50.

11. Zilker TH, Felgenhauer N, Pfab R, Drasch G, Roos G. Little effect of haemodialysis and CAVHDF on the elimination of arsenic compared to DMPS treatment. J Toxicol Clin Toxicol. 1999;37:400-1.

12. Thomson RM, Parry GJ. Neuropathies associated with excessive exposure to lead. Muscle Nerve. 2006;33(6):732-41.

13. Zhang X, Cornelis R, de Kimpe J, Mees L, Lameire N. Study of arsenicprotein binding in serum of patients on continuous ambulatory peritoneal dialysis. Clin Chem. 1998;44(1):141-7.

14. Lai MW, Boyer EW, Kleinman ME, Rodig NM, Ewald MB. Acute arsenic poisoning in two siblings. Pediatrics. 2005;116(1):249-57.

15. Zhang X, Cornelis R, Mees L, Vanholder R, Lameire N. Chemical speciation of arsenic in serum of uraemic patients. Analyst. 1998;123(1):13-7.

16. Aposhian $\mathrm{HV}$, Maiorino RM, Gonzalez-Ramirez D, Zuniga-Charles $\mathrm{M}, \mathrm{Xu} Z$, Hurlbut KM, Junco-Munoz P, Dart RC, Aposhian MM. Mobilization of heavy metals by newer, therapeutically useful chelating agents. Toxicology. 1995; 97(1-3):23-38.

17. Osterloh J, Becker CE. Pharmacokinetics of CaNa2EDTA and chelation of lead in renal failure. Clin Pharmacol Ther. 1986;40(6):686-93.

18. Tillotson JA, Boswell G, Kincannon L, Speckman CL. The biological fate of 14C-dimercaptosuccinic acid in monkeys and rabbits. Mil Med. 1989; 154(9):444-9.

19. Maiorino RM, Xu ZF, Aposhian HV. Determination and metabolism of dithiol chelating agents. XVII. In humans, sodium 2,3-dimercapto-1propanesulfonate is bound to plasma albumin via mixed disulfide formation and is found in the urine as cyclic polymeric disulfides. J Pharmacol Exp Ther. 1996;277(1):375-84.

20. Babiker MM. Binding of [51 Cr] ethylenediaminetetraacetate to proteins of human plasma. J Physiol. 1986;374:117-22.

21. Maiorino RM, Akins JM, Blaha K, Carter DE, Aposhian HV. Determination and metabolism of dithiol chelating agents: $X$. in humans, meso-2,3- 
dimercaptosuccinic acid is bound to plasma proteins via mixed disulfide formation. J Pharmacol Exp Ther. 1990;254(2):570-7.

22. Howland MA. Antidotes in Depth - Dimercaprol (British Anti-Lewisite or BAL). In: Flomenbaum NE, Goldfrank LR, Hoffman RS, Howland MA, Lewin NA, Nelson LS, editors. Goldfrank's Toxicologic Emergencies, 8th Ed. New York: McGraw-Hill Education - Europe; 2006. p. 1266-8. https:/www. bookdepository.com/Goldfranks-Toxicologic-Emergencies-Eighth-EditionLewis-R-Goldfrank/9780071437639.

23. de Graaf M, Boven E, Scheeren HW, Haisma HJ, Pinedo HM. Betaglucuronidase-mediated drug release. Curr Pharm Des. 2002;8(15):1391-403.

24. Giberson A, Vaziri ND, Mirahamadi K, Rosen SM. Hemodialysis of acute arsenic intoxication with transient renal failure. Arch Intern Med. 1976; 136(11):1303-4.

25. Blythe D, Joyce DA. Clearance of arsenic by haemodialysis after acute poisoning with arsenic trioxide. Intensive Care Med. 2001;27(1):334.

26. Smith $\mathrm{SB}$, Wombolt DG, Venkatesan R. Results of hemodialysis \& hemoperfusion in the treatment of acute arsenic ingestion. Clin Exp Dial Apheresis. 1981;5(4):399-404.

27. Levin-Scherz JK, Patrick JD, Weber FH, Garabedian C Jr. Acute arsenic ingestion. Ann Emerg Med. 1987;16(6):702-4.

28. Fesmire FM, Schauben JL, Roberge RJ. Survival following massive arsenic ingestion. Am J Emerg Med. 1988;6(6):602-6.

29. Hantson P, Haufroid V, Buchet JP, Mahieu P. Acute arsenic poisoning treated by intravenous dimercaptosuccinic acid (DMSA) and combined extrarenal epuration techniques. J Toxicol Clin Toxicol. 2003;41(1):1-6.

30. Adam B. DMPS und Dimercaprol in der Therapie der akuten Arsenintoxikation. In: Dissertation. Germany: Technical University of Munich; 2004. https://mediatum.ub.tum.de/doc/602356/602356.pdf.

31. Aposhian HV, Carter DE, Hoover TD, Hsu CA, Maiorino RM, Stine E. DMSA, DMPS, and DMPA--as arsenic antidotes. Fundam Appl Toxicol. 1984:4(2 Pt 2):S58-70.

32. Guha Mazumder DN, Ghoshal UC, Saha J, Santra A, De BK, Chatterjee A, Dutta S, Angle CR, Centeno JA. Randomized placebo-controlled trial of 2,3-dimercaptosuccinic acid in therapy of chronic arsenicosis due to drinking arsenic-contaminated subsoil water. J Toxicol Clin Toxicol. 1998:36(7):683-90.

33. Bradberry S, Vale A. Dimercaptosuccinic acid (succimer; DMSA) in inorganic lead poisoning. Clin Toxicol (Phila). 2009:47(7):617-31.

34. Holubek WJ, Hoffman RS, Goldfarb DS, Nelson LS. Use of hemodialysis and hemoperfusion in poisoned patients. Kidney Int. 2008;74(10):1327-34.

35. Shalkham AS, Kirrane BM, Hoffman RS, Goldfarb DS, Nelson LS. The availability and use of charcoal hemoperfusion in the treatment of poisoned patients. Am J Kidney Dis. 2006;48(2):239-41.

36. Sheabar FZ, Yannai S, Taitelman U. Efficiency of arsenic clearance from human blood in vitro and from dogs in vivo by extracorporeal complexing haemodialysis. Pharmacol Toxicol. 1989;64(4):329-33.

37. Smith HD, King LR, Margolin EG. Treatment of Lead Encephalopathy. The Combined Use of Edetate and Hemodialysis. Am J Dis Child. 1965; 109:322-4.

38. Mehbod H. Treatment of lead intoxication. Combined use of peritoneal dialysis and edetate calcium disodium. JAMA. 1967;201(12):972-4.

39. Pedersen RS. Lead poisoning treated with haemodialysis. Scand J Urol Nephrol. 1978;12(2):189-90

40. Roger SD, Crimmins D, Yiannikas C, Harris DC. Lead intoxication in an anuric patient: management by intraperitoneal EDTA. Aust NZ J Med. 1990;20(6): 814-7.

41. Kessler M, Durand PY, Hestin D, Cao Huu T, Renoult E, Prenat E, Chanliau J, Kaminski P, Duc M. Elevated body lead burden from drinking water in endstage chronic renal failure. Nephrol Dial Transplant. 1995;10(9):1648-53.

42. Kessler M, Durand PY, Huu TC, Royer-Morot MJ, Chanliau J, Netter P, Duc M. Mobilization of lead from bone in end-stage renal failure patients with secondary hyperparathyroidism. Nephrol Dial Transplant. 1999;14(11):2731-3.

43. Barats MS, Gonick HC, Rothenberg S, Balabanian M, Manton WI. Severe leadinduced peripheral neuropathy in a dialysis patient. Am J Kidney Dis. 2000; 35(5):963-8.

44. Roberts DM, Singer RF. Lead mobilization study and the clearance of intravenous CaNa2EDTA in a patient with end-stage renal failure on hemodialysis. J Clin Pharmacol. 2012;52(1):110-3.

45. Chisolm JJ Jr. Treatment of acute lead intoxication--choice of chelating agents and supportive therapeutic measures. Clin Toxicol. 1970;3(4):527-40.
46. Lee BK, Schwartz BS, Stewart W, Ahn KD. Provocative chelation with DMSA and EDTA: evidence for differential access to lead storage sites. Occup Environ Med. 1995;52(1):13-9.

47. Tandon SK, Singh S, Jain VK. Efficacy of combined chelation in lead intoxication. Chem Res Toxicol. 1994;7(5):585-9.

48. Hruby K, Donner A. 2,3-Dimercapto-1-propanesulphonate in heavy metal poisoning. Med Toxicol Adverse Drug Exp. 1987;2(5):317-23.

49. Chisolm JJ Jr, Thomas DJ. Use of 2,3-dimercaptopropane-1-sulfonate in treatment of lead poisoning in children. J Pharmacol Exp Ther. 1985;235(3): 665-9.

50. Moore DF, O'Callaghan CA, Berlyne G, Ogg CS, Davies HA, House IM, Henry JA. Acute arsenic poisoning: absence of polyneuropathy after treatment with 2,3-dimercaptopropanesulphonate (DMPS). J Neurol Neurosurg Psychiatry. 1994;57(9):1133-5.

51. Wax PM, Thornton CA. Recovery from severe arsenic-induced peripheral neuropathy with 2,3-dimercapto-1-propanesulphonic acid. J Toxicol Clin Toxicol. 2000:38(7):777-80.

52. Aposhian HV, Arroyo A, Cebrian ME, del Razo LM, Hurlbut KM, Dart RC, Gonzalez-Ramirez D, Kreppel H, Speisky H, Smith A, et al. DMPS-arsenic challenge test. I: increased urinary excretion of monomethylarsonic acid in humans given dimercaptopropane sulfonate. J Pharmacol Exp Ther. 1997; 282(1):192-200

53. Guha Mazumder DN, De BK, Santra A, Ghosh N, Das S, Lahiri S, Das T. Randomized placebo-controlled trial of 2,3-dimercapto-1-propanesulfonate (DMPS) in therapy of chronic arsenicosis due to drinking arseniccontaminated water. J Toxicol Clin Toxicol. 2001:39(7):665-74.

\section{Publisher's Note}

Springer Nature remains neutral with regard to jurisdictional claims in published maps and institutional affiliations.

Ready to submit your research? Choose BMC and benefit from:

- fast, convenient online submission

- thorough peer review by experienced researchers in your field

- rapid publication on acceptance

- support for research data, including large and complex data types

- gold Open Access which fosters wider collaboration and increased citations

- maximum visibility for your research: over $100 \mathrm{M}$ website views per year

At $\mathrm{BMC}$, research is always in progress.

Learn more biomedcentral.com/submissions 